\title{
The impact of seed predation and browsing on natural sessile oak regeneration under different light conditions in an over-aged coppice stand
}

\author{
Jirí Kamler ${ }^{(1)}$, Lumír \\ Dobrovolný (2), Jakub Drimaj ${ }^{(1)}$, \\ Jan Kadavý (3), Michal Kneifl ${ }^{(3)}$, \\ Zdenek Adamec ${ }^{(3)}$, Robert \\ Knott ${ }^{(2)}$, Antonín Martiník ${ }^{(2)}$, \\ Radim Plhal (1), Jaroslav Zeman ${ }^{(1)}$, \\ Jan Hrbek ${ }^{(1)}$
}

\begin{abstract}
Sessile oak (Quercus petraea (Matt.) Liebl.) is one of the most important commercial species cultivated at low altitudes in the Czech Republic, and overaged coppices are a significant part of oak stands in the region. In order to secure a high-valuable timber production (e.g., through conversion of such stands into coppices-with-standards), knowledge of the potential and limits of generative regeneration is essential. This study was conducted in three oakdominated over-aged coppice stands in different stages of conversion into coppices-with-standards and characterized by different basal area (BA, from 9.3 to $14.1 \mathrm{~m}^{2} \mathrm{ha}^{-1}$ ) and relative diffuse radiation (ISF, from 12.1 to $35.5 \%$ ). The study stands were compared with respect to seed predation following acorn fall and oak regeneration parameters. At the time of their fall the acorns represented a sought-after source of food for large mammals (particularly wild boar). At the end of acorn fall, $13-67 \%$ acorns were lost due to animal predation. A control evaluation conducted the following spring revealed a decrease of $92-97 \%$ in fallen acorns. Despite the major animal impact, a high reserve of acorns and saplings remained in the stands (4 600-29 000 acorns and 66000 310000 saplings per ha). With increasing light intensity the oak regeneration density decreased, while the height and age variability of oak regeneration increased. Although saplings were capable of surviving several years under unfavorable light conditions (even below $12 \%$ ISF), they require a minimum of $20 \%$ ISF (i.e., BA $<16 \mathrm{~m}^{2} \mathrm{ha}^{-1}$ ) to achieve sustainable height increment. Based on our results, for conversion of such stands into coppices-with-standards we recommend a maximum of 200 reserved trees $\left(B A=16 \mathrm{~m}^{2} \mathrm{ha}^{-1}\right)$ to achieve successful height growth of the understorey.
\end{abstract}

Keywords: Over-aged Coppice, Quercus petraea, Natural Regeneration, Herbivore Impact, Acorn, Light Intensity, Wild Boar

economic reasons and for enhancing forest stand stability and species diversity. In the lower elevation areas of the Czech Republic (hereafter $C R$ ), sessile oak (Quercus pe-
Modern techniques of forest regenera-
Moduction tion in Central Europe aim at an optimal utilization of natural regeneration, both for traea (Matt.) Liebl.) is one of the most important commercial species. The natural proportion of oak in the $C R$ is estimated to be about $19 \%$ of the forest area, with a total stand area consisting of $96 \%$ high forest, $1.9 \%$ coppice-with-standards and $0.7 \%$ low forests. The relatively significant proportion of oak high forests is actually represented by over-aged coppices (i.e., stands of vegetative origin with a longer rotation period) with age similar to that of high forests (i.e., stands of generative origin).

There are various silvicultural systems prescribing how to manage stands using vegetative or generative regeneration or both (Pond et al. 2014). In this context, a proportion of generative oak regeneration in vegetative-regenerated coppices is often kept for a high-valued timber production, as in the coppice-with-standards management. Such silvicultural system consists in a two-storied stand with an upper story of trees of different ages (standards) and a lower storey dominated by stems origina- 
ted from sprouts. The harvest of standards occurs periodically (usually 30 years Hochbichler 1993) and simultaneously with the lower story harvesting. Approximately 50-100 trees of new generation per ha are usually left in the lower story to replace older standards which are selectively harvested. Standards are ordinarily divided into four age cohorts (31-60, 61-90, 91-120 and $121+$ years), and selected for harvesting based on criteria such as their economic value, health, age and the surrounding stand density (Bruckman et al. 2011).

Knowledge of the potential and limits of oak generative regeneration in coppicewith-standards stands is essential for their maintenance and stability. However, the success of natural regeneration is conditioned by a number of biotic and abiotic factors (Van Ginkel et al. 2013), in particular the climatic conditions (Pérez-Ramos et al. 2010), stand structure (Nopp-Mayr et al. 2012), seed predation (Focardi et al. 2000) or annual shoot browsing (Bobiec et al. 2011, Jensen et al. 2012).

Oak reaches fructification at the age of 40-50 years in open stands and $70-80$ years in closed stands. Fruit production in open stands occurs almost every year, while in closed stands every 4-8 years (mast years). The mature stand production is $0.7-2.0 \mathrm{t}$ acorns ha ${ }^{-1}$, a well-developed free-growing oak produces $40-100 \mathrm{~kg}$ acorns year ${ }^{-1}$. Mast years with production exceeding 50 acorns $\mathrm{m}^{-2}$ are rare, mainly due to late frost and insect pests (predominantly Tortrix viridana and Thaumetopoea processionea) destroying the first blossoms. Further, part of the mast is consumed by birds and squirrels and attacked by insect pests while still on the tree. Losses occurring after seed fall are even more substantial. Seeds on the ground are subjected to a complex of negative abiotic and biotic factors, mainly predation (insects, birds, mice, squirrels, ungulates), water availability, late frost, fungal attack and diseases (Reif \& Gärtner 2007). On the other hand, animals (particularly rodents and birds) play a positive role in acorn dispersal, with jays being able to spread acorns up to several kilometers (Kollmann \& Schill 1996, Gómez 2003). However, in autumn acorns represent a source of a highly attractive food for all ungulates (Jedrzejewska et al. 1994) and rodents (Pucek et al. 1993). The cumulative impact of all consumers may result in the destruction of all oak seeds and sapling production (Cutini et al. 2012, Van Ginkel et al. 2013). Cutini et al. (2012) described the high yearly variability of seed production as a defense strategy for oaks, resulting in the satiation of consumers in mast years and their starvation in the others (the "predator satiation" hypothesis). Indeed, a direct correlation between the occurrence of mast years and the density of consumers has been confirmed for wild boar (Groot Bruinderink et al. 2009) or rodents and birds (Wolff 1996, Clotfelter et al. 2007).

Successful natural regeneration of oak stands is suppressed by ruminant ungulates, such as roe deer (Capreolus capreolus) and red deer (Cervus elaphus), that can cause significant damage to stand regeneration by retarding tree growth (Kuiters et al. 1996, Bokdam \& Gleichman 2000) or preventing seed emergence. However, the population of free living ruminants in the Czech Republic is relatively stable over time, while the abundance of wild boar (Sus scrofa) has been recently increasing (Massei et al. 2011), leading to an extended consumption of acorns and a consequent reduction of the natural regeneration of oak stands (Focardi et al. 2000). Wild boar is characterized by a high ecological adaptability and reproductive potential, and feeds on nourishment of high nutritional value (Van Wieren 2000), such as seeds and field crops in spring/summer and forest food from autumn to spring (Schley \& Roper 2003). In relation to forests management, wild boar had not been perceived as a harmful species for a long time, as its disturbance of the topsoil is considered beneficial for stand regeneration (Scott et al. 2000). However, its current high abundance and feeding behavior can dramatically impact on forest ecosystems and thus requires a closer attention.

Light availability is another major limiting factor affecting the survival, growth and competitive ability of oak regeneration (particularly with respect to shade-tolerant species, such as beech, hornbeam or lime). Sessile oak is a shade-tolerant species in the earlier life-cycle stages, being able to survive at only $15 \%$ of the full solar radiation. However, at least $20 \%$ of relative radiation is required for its sustainable growth, with an optimum relative light intensity of $20-40 \%$ and $25-50 \%$ for one-year-old and two-year-old saplings, respectively (Reif \& Gärtner 2007). At older age, oak is rather a heliophilous species. Light reduction results in higher height increment, larger leaf area and a higher content of chlorophyll, but also in an insufficient development of the root system, lower metabolism, lower assimilatory capacity, and generally lower growth performances.

The natural regeneration of oak stands is therefore affected by many factors. Tree density is related to seed production and distribution, and high density strongly limits sapling growth by reducing light intensity and water availability. Moreover, the success of regeneration is influenced by seed consumption and shoots browsing caused by mammals. The aim of the study was to evaluate the impact of wild boar, roe deer and rodents on acorn abundance and on the growth of oak regeneration under different light conditions in an oak over-aged coppice stand.

\section{Materials and methods}

\section{Study area}

The study area was located in the southern part of the Czech Republic near the town of Moravský Krumlov ( $49^{\circ} 2^{\prime} 42.849^{\prime \prime}$ $\mathrm{N}, 16^{\circ} 21^{\prime} 13.071^{\prime \prime} \mathrm{E}$ - Fig. 1). Elevation of the area ranges between 250 and $380 \mathrm{~m}$ a.s.l. and the mean annual temperature is $8-9{ }^{\circ} \mathrm{C}$. The parent rock is predominantly composed of metamorphosed granodiorites of proterozoic age, while the local soils are medium-rich with modal Cambisol as the dominant soil type. The region is characterized by the occurrence of thermophilic deciduous forests dominated by oak.

From a management perspective, the investigated oak stands are over-aged coppices and coppices-with-standards located in an area where the traditional coppicewith-standards was converted in 1955 to high forests with long rotation. Sessile oak was the dominant tree species. Afterward, a reverse conversion to coppice-with-standards was initiated 20 years ago, with the goal of enhancing biodiversity and the economic value of harvested standards.

Three oak-dominated forest stands with similar site conditions were chosen, representing loamy and fresh beech-oak forests (Viewegh et al. 2003). The selected stands differed in the intensity of canopy closure: (A) closed-canopy stand; (B) medium-canopy stand; (C): open-canopy stand (Tab. 1). All the study stands have been converted to coppice-with-standards. The process of conversion is generally divided into three steps: (1) regeneration with the preservation of standards; (2) formation of a fully established coppice-with-standards; (3) management of already established coppice-with-standards (Utinek 2004). The time range of both first and second steps should equal to the rotation of previous coppice (approx. 40 years), while the third step has unlimited length. Stands B and C are currently in the half of the first step of conversion, while the stand $A$ is at the very beginning (Tab. 1). From the beginning of the reverse conversion, sanitary thinnings (stands $A-C$ ) and the third-phase shelterwood cutting (stands B and C) were performed according to Utinek (2004). All standards were pruned.

Using the Field-Map system, a linear transect of length $150 \mathrm{~m}$ was established in the central, homogeneous part of each stand, far from neighboring stands, roads, etc. Each transect was then divided into 5meter sections using pegs, obtaining 31 sampling points per transect (overall, 93 sampling points). The following stand characteristics were evaluated within each transect (see below): (i) stand structure and light conditions; (ii) acorn production and consumption; (iii) inventory of a natural regeneration. The experimental design adopted is skecthed in Fig. 2.

Mammals which may potentially affect natural oak regeneration in the study area include wild boar (Sus scrofa) and roe deer (Capreolus capreolus). Small mammals encompass rodents: yellow-necked mouse (Apodemus flavicollis), wood mouse (Apodemus sylvaticus) and the bank vole (Myodes glareolus). The study area was situated 
in the vicinity of a game preserve surrounded by fences, which however did not hampered wild boars from moving inside and outside the preserve. Farmland did not provide any shelter or sufficient food supply for the wild boars during the experiment. Throughout the monitored period wild boar spent most of the daytime hidden in the thick brushwood and ventured out at night to forage in the open parts of the stands and in the fields surrounding the studied forest complex.

\section{Stand structure and light conditions}

All trees exceeding $50 \mathrm{~mm}$ diameter at breast height $(1.3 \mathrm{~m}$ above the ground) were localized within $25 \mathrm{~m}$ at each side of the transect (including the endpoints), covering a total area $9463 \mathrm{~m}^{2}$ in each stand. We determined the species of each tree and measured its height and diameter at breast height. Hemispherical photographs were also taken ( $1.5 \mathrm{~m}$ above the ground, weather: overcast) at each sampling point along the transect (93 photographs in total) using a digital Nikon Coolpix 4500 camera with FC-E8 fisheye convertor (camera settings: Shooting-Mode: P; Programmed: Auto; Focus Mode: infinity; image format: TIFF). The indirect site factor ISF (i.e., the intensity of relative diffuse radiation) was evaluated using the WinsCanopy ${ }^{\circledR}$ 2008a software package (Regent Instruments Inc., Canada) using the following settings: automatic thresholding, no other corrections. The ISF values differed significantly in the individual stands $A, B, C\left(F_{[2,90]}\right.$ $=37.367, \mathrm{p}<0.001-$ Tab. 2 ).

\section{Natural regeneration inventory}

A circular plot of $1 \mathrm{~m}^{2}$ was established centered at each sampling point along the transects, and the species, density and height class of each sapling within the plot were determined. Sample oak saplings were also characterized by the height increments $(\mathrm{cm})$ of the two preceding years (mean of both values), height $(\mathrm{cm})$ and age (number of internodes). Based on the relationship between height and age (Fig. 3), we divided all saplings into four height/age classes (1-4), each characterized by a given height and age (Tab. 3, Fig. 3).

\section{Acorn production and consumption}

To monitor seed fall and its consumption, three plots were placed in close proximity at each sampling point along the transect, each covering $0.25 \mathrm{~m}^{2}$ (15 sets in each stand, 45 in total). The first plot (seed trap) was used to determine the total seed fall, and consisted of a metal stand and a clothmade seed trap which prevented animals from consuming the acorns. The second plot (fenced) was surrounded by a $1 \mathrm{~m}$-high wire mesh with $10 \times 10 \mathrm{~cm}$ openings which enabled unlimited access to small mammals, but prevented ungulates from consuming the acorns. The third plot (control) was only marked out and the acorns within it were freely accessible to animals. The

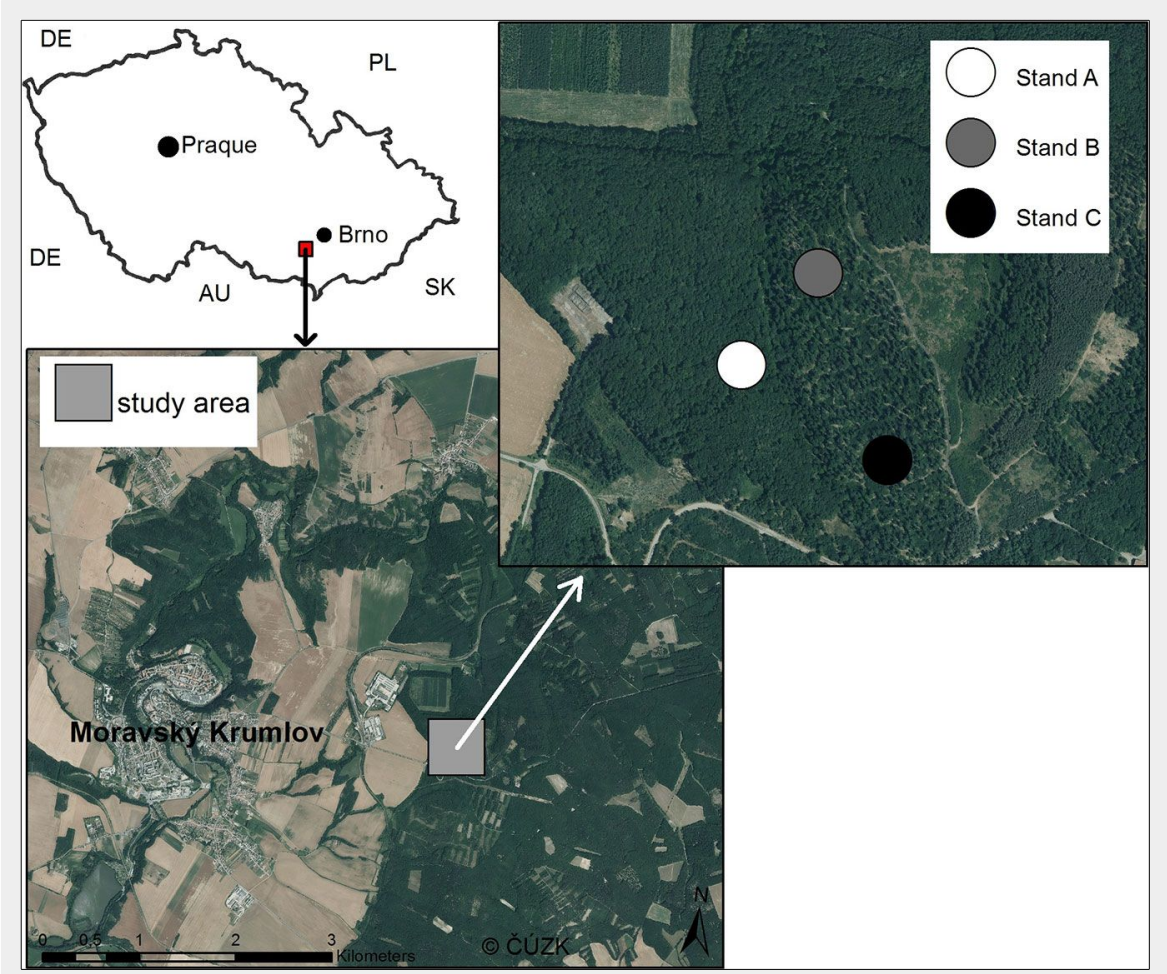

Fig. 1 - Location of the study area with indication of the three study stands.

Tab. 1 - Characteristics of studied forest stands taken from the management plan. (QP): Sessile oak, Quercus petraea (Matt.) Liebl.; (CB): European hornbeam, Carpinus betulus L.; (TC): small-leaved lime, Tilia cordata Mill.; (PS): Scots pine, Pinus sylvestris L.; (LD): European larch, Larix decidua Mill.

\begin{tabular}{cccllcc}
\hline Stand & $\begin{array}{c}\text { Area } \\
\text { (ha) }\end{array}$ & $\begin{array}{c}\text { Age } \\
\text { (years) }\end{array}$ & Species composition & $\begin{array}{c}\text { Standing volume } \\
\left.\text { ( }^{3} \mathbf{h a}^{-1}\right)\end{array}$ & $\begin{array}{c}\text { Stand density } \\
(\%)\end{array}$ \\
\hline A & 14.05 & 85 & QP 97\%; CB 2\%; TC 1\% & 270 & 100 \\
\hline B & 9.91 & 101 & QP 95\%; PS 3\%; LD 1\%; CB 1\% & 145 & 50 \\
\hline C & 9.91 & 101 & QP 95\%; PS 3\%; LD 1\%; CB 1\% & 93 & 30 \\
\hline
\end{tabular}

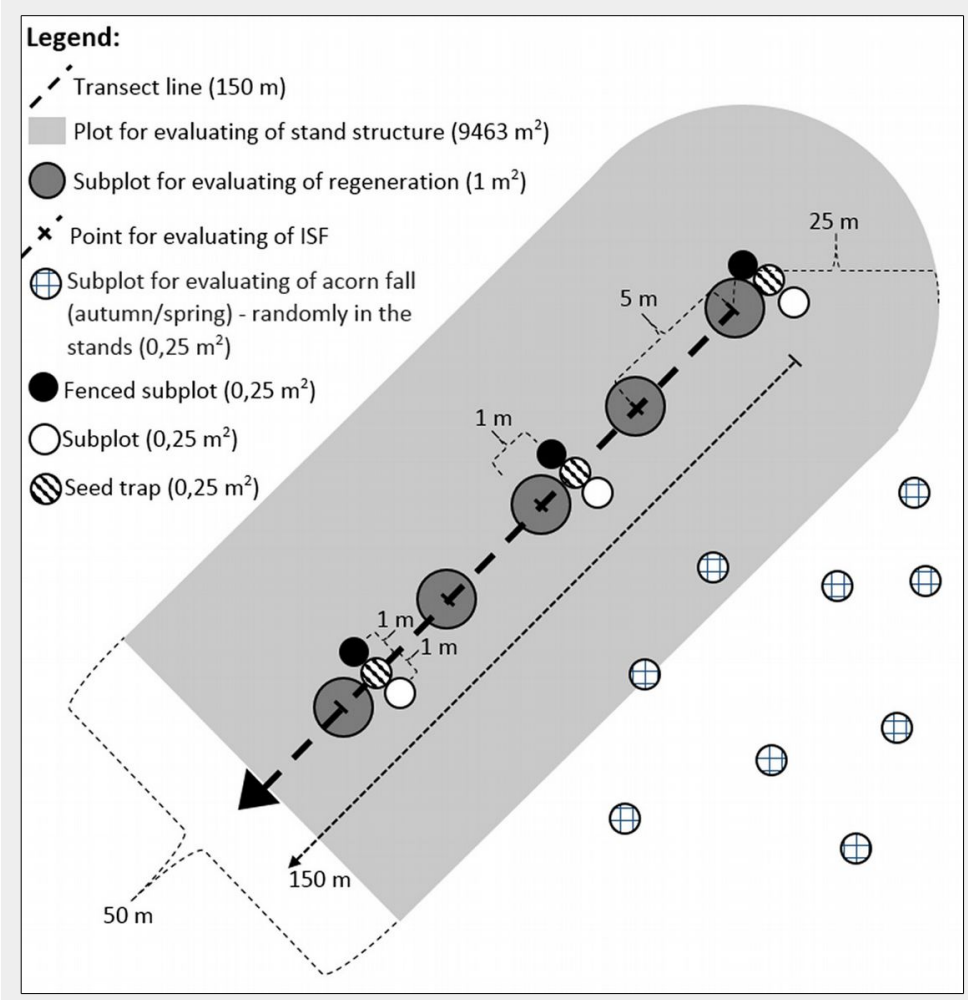

Fig. 2 -

Schematic representation of the experimental design adopted in this study. 
Tab. 2 - Altitude, stand composition, diameter at breast height (DBH), basal area and indirect site factor (ISF) of the transects. (QP): Quercus petraea (Matt.) Liebl.; (CB): Carpinus betulus L.; (TC): Tilia cordata Mill.; (PS): Pinus sylvestris L.; (SD): standard deviation.

\begin{tabular}{cclcccc}
\hline Stand & $\begin{array}{c}\text { Altitude } \\
(\mathrm{m} \text { a.s.l. })\end{array}$ & $\begin{array}{l}\text { Species } \\
\text { composition (\%) }\end{array}$ & $\begin{array}{c}\text { Trees } \\
\left(\mathrm{n} \mathrm{ha}^{-1}\right)\end{array}$ & $\begin{array}{c}\mathrm{DBH}(\mathrm{cm}) \\
\mathrm{mean} \pm \mathrm{SD}\end{array}$ & $\begin{array}{c}\text { Basal area } \\
\left(\mathrm{m}^{2} \mathrm{ha}^{-1}\right)\end{array}$ & $\begin{array}{c}\text { ISF }(\%) \\
\text { mean } \pm \text { SD } \\
(\text { median })\end{array}$ \\
\hline A & $340-355$ & QP 100 (PS+) & 401 & $22.4 \pm 7.5$ & 19.1 & $\begin{array}{c}12.1 \pm 2.0 \\
(11.7)\end{array}$ \\
& & & 243 & $26.2 \pm 6.0$ & 14.1 & $\begin{array}{c}25.5 \pm 10.9 \\
(22.7)\end{array}$ \\
B & $345-365$ & QP 100 & & & & $\begin{array}{c}35.3 \pm 14.3 \\
(31.8)\end{array}$ \\
\hline
\end{tabular}

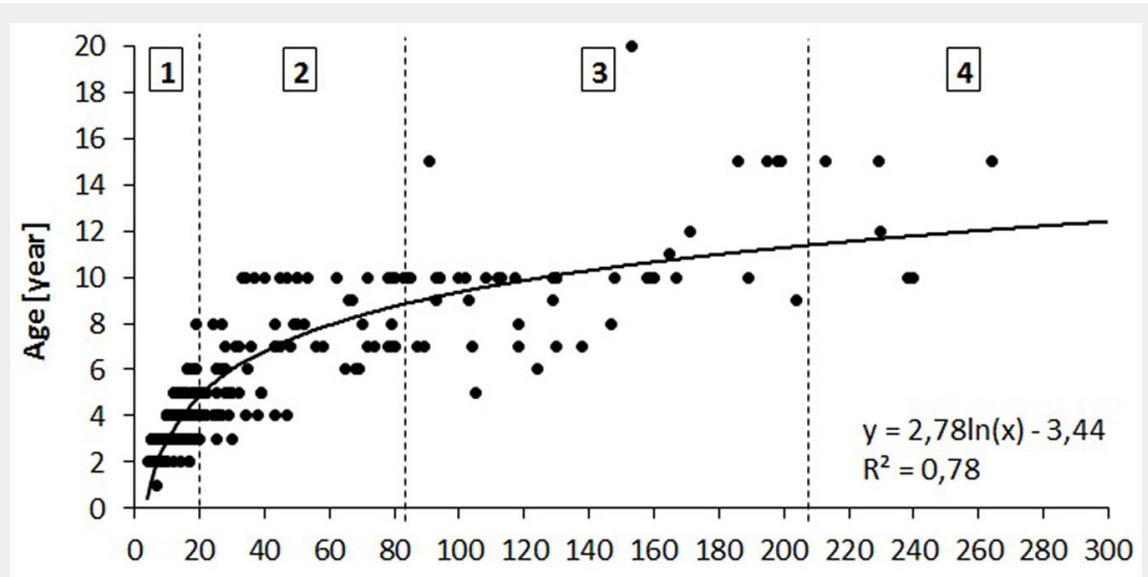

Fig. 3 - Relationship between height and age of oak saplings in the three studied stands and the derived height/age classes (1-4) for saplings.

consumption by small mammals was calculated as the difference between the total seed fall in the seed trap and the number of acorns left in the fenced plot. The consuption by ungulates was assessed based on the acorns left in the open plot. We checked the plots at one week intervals throughout the seed fall period (a total of 8 samplings from $10^{\text {th }}$ September 2013 to $9^{\text {th }}$ November 2013).

The intensity of acorn consumption during the seed fall determined from 15 sets of plots was used to estimate the total stand production. The counting of acorns was conducted after the seed fall (at the time

Tab. 3 - Characteristics of the height/age classes (1-4) of oak saplings. The age of saplings in each height class (Expected Age) was derived from the relationship shown in Fig. 3.

\begin{tabular}{lcc}
\hline $\begin{array}{l}\text { Height class } \\
\text { (cm) }\end{array}$ & $\begin{array}{c}\text { Expected Age } \\
\text { (year) }\end{array}$ & $\begin{array}{c}\text { Height/ } \\
\text { age class }\end{array}$ \\
\hline$\leq 20$ & $1-5$ & 1 \\
$20.1-50$ & $6-9$ & 2 \\
$50.1-80$ & $6-9$ & 2 \\
$80.1-130$ & $10-11$ & 3 \\
$130.1-200$ & $10-11$ & 3 \\
$200.1-300$ & $12-13$ & 4 \\
$300.1-400$ & $12-13$ & 4 \\
\hline
\end{tabular}

of the last check of the sample plots) at 100 randomly selected plots covering 0.25 $\mathrm{m}^{2}$ in each stand, i.e., a total of 300 plots. The characteristics of trees in the vicinity of each plot were also taken. The determined quantity of acorns sampled during this oneoff monitoring was adjusted to the real number of fallen acorns by including the percentage of acorns which had been consumed by all animals by the sampling date (data from subplots on the lines). The survey was repeated in the spring, when acorns began to germinate, and the number of acorns preserved at the plots until the beginning of the vegetative stage was counted.

\section{Data analysis}

To compare acorn production, acorn consumption and the density of oak saplings in the individual stands, one-way ANOVA (analysis of variance) and Tukey's post-hoc HSD test were used. The same analysis was also applied for the comparison of indirect site factor (ISF) between the monitored stands. For stands $B$ and $C$, two-sample $t$ test was used to compare the density of oak saplings in height/age classes 3 and 4 . All data were tested for normality by Shapiro-Wilk's test. The data were normally distributed ( $p>0.05$ in all cases). All analyses were performed at a significance level $a=0.05$. Linear regression was used to estimate the relationships between measured characteristics of stand/light and oak saplings.

\section{Results}

\section{Stand characteristics and natural regeneration}

A total of 722 trees were surveyed in the studied stands. At the time of establishing the study areas, the monitored stands were almost exclusively composed of oaks, except 1 individual of hornbeam and 1 individual of lime (Tab. 2). Other tree species were found only in the shrub layer (hornbeam in dense stand).

Oak dominated the composition of natural regeneration in all studied stands (Tab. 4). While in the dense stand A (ISF $12.1 \%$ Tab. 2) only saplings in the height/age class 1 or 2 were detected (age: 1-9 years; height: up to $80 \mathrm{~cm}$ ), in the more opened stands $B$ and C (ISF; $25.5 \%$ and $35.3 \%$, respectively Tab. 2) all four classes were present (age: 120 years; height: up to $400 \mathrm{~cm}$ - Tab. 4). The highest density of oak saplings was found in the stand A. The comparison of the average density of individuals in the height/age class 1 revealed statistically significant differences among the three stands $\left(\mathrm{F}_{[2,90]}=\right.$ 26.177, $p<0.001$ ). Contrastingly, the comparison of the average density of saplings in classes 2, 3 and 4 revealed no statistically significant differences among stands ( $p$ > $0.05)$.

The relationship of the relative diffuse radiation with density $\left(R^{2}=0.14\right)$ and height increment $\left(R^{2}=0.58\right)$ of oak saplings was verified by a regression analysis (Fig. 4, Fig. 5). A decrease in sapling density was recorded when ISF values exceeded $15 \%$, while a distinct increase in the height increment was recorded when ISF values exceeded $20 \%$. In this context, a reduction of the stand basal area below $16 \mathrm{~m}^{2} \mathrm{ha}^{-1}$ is necessary to enhance height increment of oak saplings (Fig. 6).

\section{Acorn production}

Taking into consideration the acorn consumption in individual stands, we assessed a production of 731000 (stand A), 350000 (stand B) and 108000 (stand C) acorns per hectare, with significant differences among stands $\left(\mathrm{F}_{[51,180]}=2.1712, \mathrm{p}<0.001-\right.$ Tab. 3$)$. While the overall acorn production differed among stands as a consequence of the different number of trees, acorn production per tree was similar in all surveyed stands.

\section{Acorn consumption}

Acorns represented a sought-after source of food for animals in the study area. By the end of the seed fall, approximately half of the fallen acorns had been consumed, on average. The highest proportion of consumed acorns was observed in stand $C$ $(67 \%)$, where the lowest seed fall was also registered. As for stand A, 44\% acorns were consumed, while the lowest acorn con- 
Tab. 4 - Average density of the natural regeneration in the studied stands, in total and partitioned into height/age classes (1-4). Val ues in brackets are 95\% confidence intervals. (QP): Quercus petraea (Matt.) Liebl.; (CB): Carpinus betulus L.

\begin{tabular}{|c|c|c|c|c|c|c|c|c|}
\hline \multirow{2}{*}{ Stand } & \multirow{2}{*}{$\begin{array}{c}\text { Density - total } \\
\quad\left(\mathrm{n} \mathrm{ha}^{-1}\right)\end{array}$} & \multirow{2}{*}{$\begin{array}{l}\text { Species } \\
\text { Composition } \\
\text { (\%) }\end{array}$} & \multirow{2}{*}{$\begin{array}{c}\text { Density - total } \\
\text { oak }\left(\mathrm{n} \mathrm{ha}^{-1}\right)\end{array}$} & \multirow{2}{*}{$\begin{array}{c}\text { Decrease of } \\
\text { density oak \% }\end{array}$} & \multicolumn{4}{|c|}{ Oak Density $\left(\mathrm{n} \mathrm{ha}^{-1}\right)$} \\
\hline & & & & & Class 1 & Class 2 & Class3 & Class 4 \\
\hline A & $\begin{array}{c}310000.0 \\
(101136.3)\end{array}$ & QP $100 \%$ & $\begin{array}{c}310000.0 \\
(101136.3)\end{array}$ & 0 & $\begin{array}{l}298333.3 \\
(97688.3)\end{array}$ & $\begin{array}{l}11666.7 \\
(8091.3)\end{array}$ & 0.0 & 0.0 \\
\hline B & $\begin{array}{l}112758.6 \\
(29880.2)\end{array}$ & QP 99\%, CB 1\% & $\begin{array}{l}111379.3 \\
(30118.4)\end{array}$ & 64 & $\begin{array}{c}86551.7 \\
(31926.6)\end{array}$ & $\begin{array}{l}16206.9 \\
(7360.0)\end{array}$ & $\begin{array}{c}8620.7 \\
(6326.2)\end{array}$ & $\begin{array}{c}344.8 \\
(706.4)\end{array}$ \\
\hline C & $\begin{array}{c}66129.0 \\
(29959.5)\end{array}$ & QP $100 \%$ & $\begin{array}{c}66129.0 \\
(29959.5)\end{array}$ & 79 & $\begin{array}{l}14516.1 \\
(5902.3)\end{array}$ & $\begin{array}{c}27096.8 \\
(14462.6)\end{array}$ & $\begin{array}{c}24516.1 \\
(17612.6)\end{array}$ & $\begin{array}{c}1935.5 \\
(1473.1)\end{array}$ \\
\hline
\end{tabular}

Fig. 4 - Relation between relative diffuse radiation (ISF) and oak regeneration density in the three investigated stands (A, B and C).

Fig. 5 - Relationship between relative diffuse radiation (ISF) and oak height increment in the three investigated stands (A, B and C).

Fig. 6 - Relationship between the stand basal area and the relative diffuse radiation (ISF) in the investigated oak stands (A. B. and C).
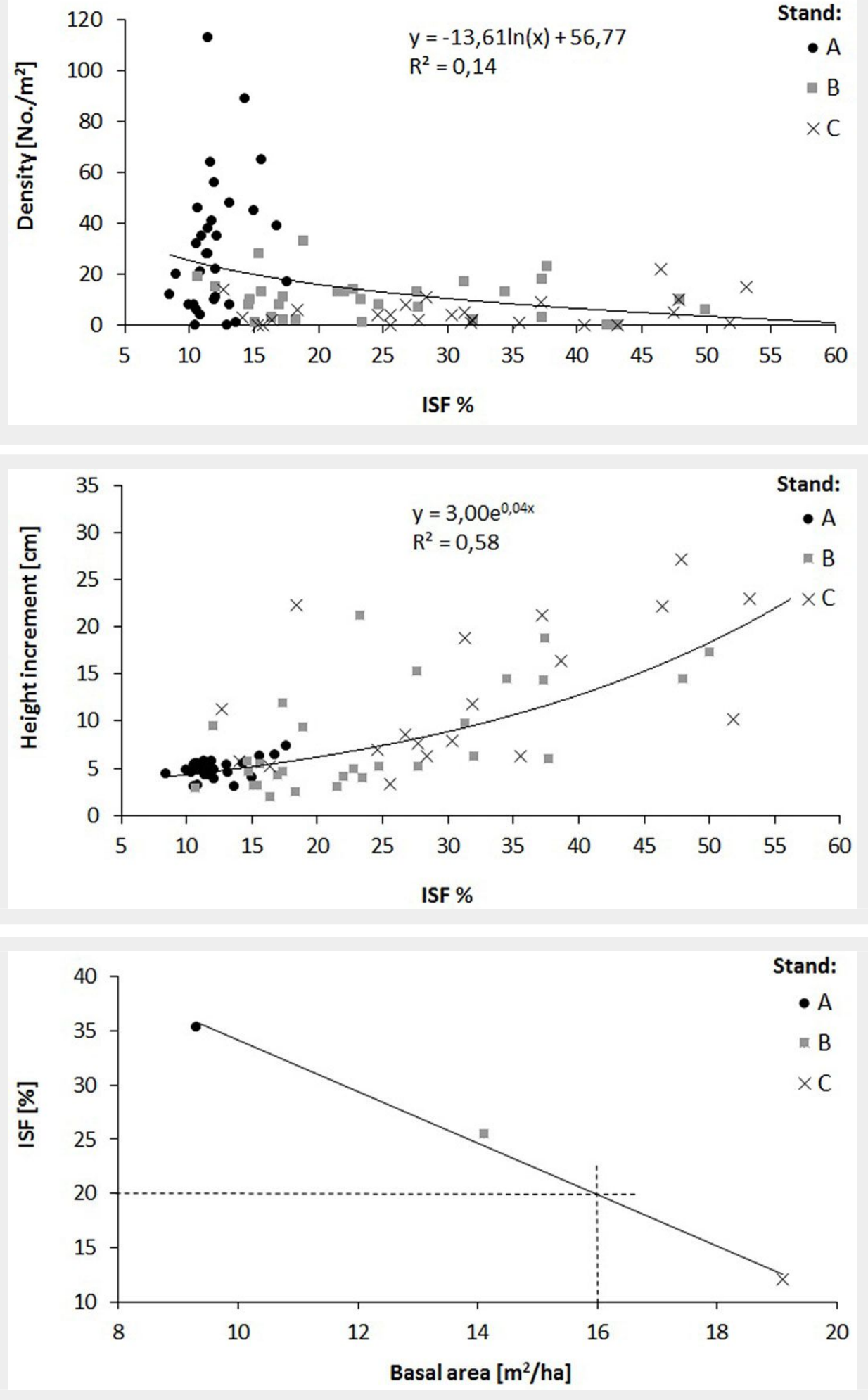
Tab. 5 - Acorn production in the monitored stands and intensity of acorn consumption by small mammals and ungulates during the seed fall.

\begin{tabular}{lrrc}
\hline Stand & A & B & C \\
\hline Production (thousands of acorns ha ${ }^{-1}$ ) & 731 & 350 & 108 \\
\hline Consumption during the seed fall (\%) & 44 & 13 & 67 \\
\hline Small mammals (\%) & 40 & 7 & 18 \\
Ungulates (\%) & 4 & 6 & 49 \\
\hline Remnants in spring (thousands of acorns ha ${ }^{-1}$ ) & 22 & 29 & 4.6 \\
\hline
\end{tabular}

sumption intensity was recorded in stand $\mathrm{C}$ (only 13\% - Tab. 5). The differences in the intensity of acorn predation among stands were not significant in all cases $\left(\mathrm{F}_{[1,293]}=\right.$ $1.171, p=0.28$ ). The quantity of acorns in spring corresponded to their production and predation. The significantly smallest amount was found in the stand $C\left(\chi^{2}=\right.$ $25.028, p<0.001)$, where acorn production was the lowest and only 4600 acorns per ha remained in spring. Over 20000 acorns were found in the remaining stands. Both large ungulates and small mammals participated in acorn consumption, albeit their proportional ratio differed significantly in individual monitored stands.

\section{Discussion}

\section{Acorn production and predation}

Acorn production and predation is the key factor influencing the process of oak natural regeneration. Our study demonstrated that acorn production in over-aged coppice stands (stand A: 73 seeds $\mathrm{m}^{-2} ; \mathrm{B}: 35$ seeds $\mathrm{m}^{-2}$; $\mathrm{C}$ : 11 seeds $\mathrm{m}^{-2}$ ) can be comparable to that of generative forests, where mast years with acorn production exceeding 50 seeds $\mathrm{m}^{-2}$ are rare (Martiník et al. 2014). Acorn production is influenced by a number of biotic and abiotic factors (Reif \& Gärtner 2007, Van Ginkel et al. 2013). Animal predation can strongly lower the density of acorns (Kelly 2002, Gómez 2003, Bobiec et al. 2011), as corroborated by the results of our study. Acorns are very attractive food preferred by many species (e.g. birds, especially wood-pigeons and jays, voles, rabbits, badgers and deer - Shaw 1968, Kelly 2002).

\section{Wild boar impact}

Wild boar is the main ungulate species in our study area. The density of roe deer was low, as reported by local forest managers. Wild boar, which is considered the major acorn consumer in other parts of the world, is not present in Great Britain (Gómez 2003). However, wild boar populations are globally growing (Tellería \& SáezRoyuela 1985, Massei et al. 2015) and expanding their range to new regions (Cai et al. 2008). This further aggravates the negative impact of the wild boar to forest stands, and represents a threat to the natural regeneration of forest tree species (Jedrzejewska et al. 1994).

Consumption of acorns by large and small mammals differed according to the canopy openness. The dense stand A with a low shrub layer showed the highest impact of small mammals, while the stand $C$ with a low density of mature trees and a rich undergrowth in the higher height/age classes (exceeding $50 \mathrm{~cm}$ ) showed the highest impact by large animals. We assume that a shelter extends the duration of animal activities (Podgórski et al. 2013, Thurfjell et al. 2013). Therefore, the proportion of acorns consumed by ungulates in a safe place was significantly higher. The importance of a shelter also underlies the typical seasonal migration of wild boar between fields and forests (Cahill et al. 2003). During the vegetation period, wild boar takes advantage of rape, cereal and maize cultures until their harvest in September or October (Schley et al. 2008). Subsequently, they move to forests where sufficient food sources and shelter are available (Frackowiak et al. 2013). Indeed, animals with adequate food supplies do not migrate far from their resting places in search of uncertain sources (Massei et al. 1997, Lemel et al. 2003), and they move to more distant places only after the local food sources have been completely depleted (Thurfjell et al. 2013). Therefore, their feeding behavior is conditioned by the distance from food sources, escape possibilities and cover opportunities (Spitz \& Janeau 1995). Such tendency of wild boar to linger within the forest in autumn and winter further increases acorn consumption and decreases the recruitment of the forest stands. In our study, $91-97 \%$ of the total acorn production was consumed from autumn to spring, similarly to previous studies (Gómez 2003). The acorn consumption by wild boar was the lowest in the stand A, devoid of cover possibilities. However, wild boar impact on the natural regeneration of trees is conditioned by other factors, such as the distance from water and other food sources, hunting activities in the stand or the length of the period spent in cropfields). Therefore, the extent of its impact on acorn survival cannot be generalized (Katona et al. 2014), and may differ from stand to stand.

\section{Rodent impact}

With regards to rodents, no increasing or decreasing trend with respect to the regeneration density or the stand characteristics was found in this study. However, acorn consumption was the highest in the stand $\mathrm{A}$, characterized by a dense regeneration up to $20 \mathrm{~cm}$. Rodents were responsi- ble for a decrease of 292000 acorns per hectare in the studied stand (40\%). Nonetheless, the absence of acorns due to rodent activities can not be considered a direct consumption, because rodents build underground food storage (Wang et al. 1999, Gómez 2003), which favor natural regeneration through seed dispersal (Kollmann \& Schill 1996). Experiments conducted by Wang et al. (1999) showed that acorns disappeared very quickly after artificial exposure due to rodent activities (all acorns disappeared within 5-6 hours since exposure during the day, or within 10 hours during the night). The study also concluded that rodents moved more than $82 \%$ of acorns to underground food storages. Focardi et al. (2000) notes that these supplies may become a source of food for wild boar in early spring, when acorns lying on the ground have already been consumed. Due to the scarcity of sufficient food source at this time, these rodent-amassed deposits of acorns may become an important factor affecting the wild boar population dynamics.

\section{Other factors affecting oak regeneration}

With respect to the estimated total regeneration density (66 000-310 000 saplings $\left.\mathrm{ha}^{-1}\right)$ the observed quantity of acorns in spring (4600-22 000 acorns ha ${ }^{-1}$ ) is more than sufficient for the purposes of forest management. The high density of natural regeneration found in this study was probably due to the accumulation of saplings from previous mast years. The density of oak regeneration decreased with increasing canopy openness, while both height and age variability of saplings increased. This is probably due to intraspecific competition (autoreduction) of oak saplings and to different growth dynamics at different age. Nevertheless, oak survived (in our case up to 9 years with a height up to 50$80 \mathrm{~cm}$ ) even under full canopy (about 12\% ISF). Generally, oak is able to survive several years at $15 \%$ relative radiation and oak sapling decrease in stocking of $0.8-0.9$ after 6-7 years. We even recorded the occasional occurrence of oak saplings under extremely low radiation (as low as 5\% ISF), according to several studies which describe oak as a shade-tolerant species in its early years (Brezina \& Dobrovolný 2011). However, based on our results oak needs at least $20 \%$ ISF for its sustainable growth. This finding is corroborated by other studies which consider relative radiation values of $30-60 \%$ as optimal for sustainable height growth (Reif \& Gärtner 2007).

We estimated also the impact of shoot browsing by roe deer. In the studied area the intensity of damaged shoots was less than $1 \%$ and had no effect on oak regeneration. Indeed, in this area characterized by mild winter and rich food supply, the roe deer prefer other food. Other biotic and abiotic factors, not only light and stand structure, influence oak saplings emer- 
gence and growth, e.g. interspecific competition, ground vegetation, drought, richness of nutrients, browsing, etc. (Reif \& Gärtner 2007). For example, at a rich site with a similar stand structure and light conditions, other species like hornbeam, field maple, ash, lime and shrubs were dominant in the natural regeneration. Consequently, in the young stands without targeted silvicultural measures the proportion of oak was less than $1 \%$. The remaining living oaks in the upper layer (about 55 indiv. $h^{-1}$ ) were distributed irregularly (cluster pattern) and their basal area reached about $5 \mathrm{~m}^{2}$. In our case, oak regeneration at the acidic site was abundant. However, to increase height growth of oak saplings a reduction of the basal area of adult oak stands under $16 \mathrm{~m}^{2}$ is recommended. For the proper mechanical stability and optimal diameter increment of the young oak stand, the density of oaks should be reduced to 10000 indiv. ha ${ }^{-1}$ through the first juvenile thinning.

\section{Conclusions}

Our results proved that over-aged coppice stands are characterized by abundant fructification and successful generative regeneration under different light conditions and despite the strong animal impact. Indeed, more than half of acorns are consumed by the end of acorn fall and less than $10 \%$ of the total remain until spring. Nevertheless, a high stocks of acorns and saplings remained in the stands. Based on the number of different height/age classes of saplings observed in this study, the regeneration capacity of the studied stands was not threatened in the past years. Although the saplings may survive under unfavorable light conditions for several years, a basal areas of less than $16 \mathrm{~m}^{2}$ $\mathrm{ha}^{-1}$ of the parent stands is required to achieve a sustainable height growth. Therefore, generative natural oak regeneration in over-aged coppice stands can be relied upon in the conversion into a coppice-with-standards, which was carried out 20 years in the studied forest stands. The results obtained provide complementary information on the widely discussed issue of the optimal number of reserved trees and optimal basal area in a stand (in our case, max. 200 reserved trees ha ${ }^{-1}$ and 16 $\mathrm{m}^{2} \mathrm{ha}^{-1}$, respectively) to secure a successful natural generative regeneration under the optimum relative diffuse radiation ( $\mathrm{min}$. $20 \%$ ISF).

\section{Acknowledgements}

This study was supported by the Ministry of Education, Youth and Sports of the Czech Republic, project No. CZ.1.07/2.3.00/ 20.0267 and by the Grant Agency of MENDELU, project No. 80/2013.

\section{References}

Bobiec A, Kuijper DPJ, Niklasson M, Romankiewicz AA, Solecka K (2011). Oak (Quercus robur L.) regeneration in early successional woodlands grazed by wild ungulates in the absence of livestock. Forest Ecology and Management 262: 780-790. - doi: 10.1016/j.foreco.20 11.05.012

Bokdam J, Gleichman JM (2000). Effects of grazing by free-ranging cattle on vegetation dynamics in a continental north-west European heathland. Journal of Applied Ecology 37: 415-431. doi: 10.1046/j.1365-2664.2000.00507.x

Bruckman VJ, Yan S, Hochbichler E, Glatzel G (2011). Carbon pools and temporal dynamics along a rotation period in Quercus dominated high forest and coppice with standards stands. Forest Ecology and Management 9: 1853-1862. doi: 10.1016/j.foreco.2011.08.006

Brezina I, Dobrovolný L (2011). Natural regeneration of sessile oak under different light conditions. Journal of Forest Science 57: 359-368. [online] URL: http://agriculturejournals.cz/pub licFiles/45152.pdf

Cahill S, Llimona F, Gracia J (2003). Spacing and nocturnal activity of wild boar Sus scrofa in a Mediterranean metropolitan park. Wildlife Biology 9: 3-13. [online] URL: http://www.parcna turalcollserola.cat/html/senglars/CAHILL_SENG LAR.pdf

Cai J, Jiang ZG, Zeng Y, Li CW, Bravery BD (2008). Factors affecting crop damage by wild boar and methods of mitigation in a giant panda reserve. European Journal of Wildlife Research 54: 723-728. - doi: 10.1007/s10344-008-0203-X

Clotfelter ED, Pedersen AB, Cranford JA, Ram N, Snajdr EA, Nolan V, Ketterson ED (2007). Acorn mast drives long-term dynamics of rodent and songbird populations. Oecologia 154: 493-503. doi: 10.1007/s00442-007-0859-z

Cutini A, Chianucci F, Chirichella R, Donaggio E, Mattioli L, Apollonio M (2012). Mast seeding in deciduous forests of the northern Apennines (Italy) and its influence on wild boar population dynamics. Annals of Forest Science 70: 493-502. doi: 10.1007/s13595-013-0282-z

Focardi S, Capizzi D, Monetti D (2000). Competition for acorns among wild boar (Sus scrofa) and small mammals in a Mediterranean woodland. Journal of Zoology 250: 329-334. - doi: 10.1111/j.1469-7998.2000.tboo777.x

Frackowiak W, Gorczyca S, Merta D, WojciuchPloskonka M (2013). Factors affecting the level of damage by wild boar in farmland in northeastern Poland. Pest Management Science 69: 362-366. - doi: 10.1002/ps.3368

Gómez JM (2003). Spatial patterns in long-distance dispersal of Quercus ilex acorns by jays in a heterogeneous landscape. Ecography 26: 573584. - doi: 10.1034/j.1600-0587.2003.03586.x

Groot Bruinderink GWTA, Hazebroek E, Van Der Voot H (2009). Diet and condition of wild boar, Sus scrofa, without supplementary feeding. Journal of Zoology 233: 631-648. - doi: 10.1111/j. 1469-7998.1994.tb05370.x

Hochbichler E (1993). Methods of oak silviculture in Austria. Annals of Forest Science 50: 583-591. doi: 10.1051/forest:19930607

Jedrzejewska B, Okarma H, Jedrzejewski W, Milkowski L (1994). Effects of exploitation and protection on forest structure, ungulate density and wolf predation in Bialowieza Primeval Forest, Poland. Journal of Applied Ecology 31: 664-676. - doi: 10.2307/2404157

Jensen AM, Götmark F, Löf M (2012). Shrubs pro- tect oak saplings against ungulate browsing in temperate broadleaved forests of conservation interest: a field experiment. Forest Ecology and Management 266: 187-193. - doi: 10.1016/j.for ec0.2011.11.022

Katona K, Fehér A, Szemethy L (2014). Evaluating the impact of wild boar on oak regeneretion in Hungary. In: Proceedings of the " $10^{\text {th }}$ International Symposium on Wild Boar and other Suids". Velenje (Slovenia) 1-5 Sep 2014. ERIC, Velenje, Slovenia, pp. 99.

Kelly DL (2002). The regeneration of Quercus petraea (sessile oak) in southwest Ireland: a 25year experimental study. Forest Ecology and Management 166: 207-226. - doi: 10.1016/S03781127(01)00670-3

Kollmann J, Schill HP (1996). Spatial patterns of dispersal, seed predation and germination during colonization of abandoned grassland by Quercus petraea and Corylus avellana. Vegetatio 125: 193-205. - doi: 10.1007/BFoo044651

Kuiters AT, Mohren GMJ, Van Wieren SE (1996). Ungulates in temperate forest ecosystems. Forest Ecology and Management 88: 1-5. - doi: 10.1016/S0378-1127(96)03876-5

Lemel J, Truve J, Soderberg B (2003). Variation in ranging and activity behaviour of European wild boar (Sus scrofa) in Sweden. Wildlife Biology 9: 29-36.

Martiník A, Dobrovoln L, Palátová E (2014). Tree growing space and acorn production of Quercus robur. Dendrobiology 71: 101-108. [online] URL: http://yadda.icm.edu.pl/yadda/element/b wmeta1.element.agro-fa34fagc-fa82-415e-9836 -ba4b73agbodc/c/17.pdf

Massei G, Genov PV, Staines BW, Gorman ML (1997). Factors influencing home range and activity of wild boar (Sus scrofa) in a Mediterranean coastal area. Journal of Zoology 242: 411423. - doi: 10.1111/j.1469-7998.1997.tb03845.x

Massei G, Kindberg J, Licoppe A, Gačic D, Sprem $\mathrm{N}$, Kamler J, Baubet E, Hofmann U, Monaco A, Ozolins J, Cellina S, Podgórski T, Fonseca C, Markov N, Pokorny B, Rosell C, Náhlik A (2015). Wild boar populations up, numbers of hunters down? A review of trends and implications for Europe. Pest management science 71: 492-500. - doi: 10.1002/ps.3965

Massei G, Roy S, Bunting R (2011). Too many hogs? A review of methods to mitigate impact by wild boar and feral hogs. Human-Wildlife Interactions 5: 79-99. [online] URL: http://www. researchgate.net/profile/Giovanna_Massei2/pu blication/256669104/

Nopp-Mayr U, Kempter I, Muralt G, Gratzer G (2012). Seed survival on experimental dishes in a central European old-growth mixed-species forest - effects of predator guilds, tree masting and small mammal population dynamics. Oikos 121: 337-346. - doi: 10.1111/j.1600-0706.2011.1909 9. $\mathrm{x}$

Pérez-Ramos IM, Ourcival JM, Limousin JM, Rambal S (2010). Mast seeding under increasing drought: results from a long-term data set and from a rainfall exclusion experiment. Ecology 91: 3057-3068. - doi: 10.1890/09-2313.1 Podgórski T, Bas G, Jedrzejewska B, Sönnichsen L, Sniezko S, Jedrzejewski W, Okarma H (2013). Spatiotemporal behavioural plasticity of wild boar (Sus scrofa) under contrasting conditions of human pressure: primeval forest and metro- 
politan area conditions of human pressure: primeval forest and metropolitan area. Journal of Mammalogy 91: 109-119. - doi: 10.1644/12MAMM-A-038.1

Pucek Z, Jedrzejewski W, Jedrzejewska B, Pucek $M$ (1993). Rodent population dynamics in a primeval deciduous forest (Bialowieza National Park) in relation to weather, seed crop, and predation. Acta Theriologica 38: 199-232. - doi: 10.4098/AT.arch.93-18

Pond NC, Froese RE, Nagel LM (2014). Sustainability of the selection system in northern hardwood forests. Forest Science 60: 374-381. - doi: $10.5849 /$ forsci.12-113

Reif A, Gärtner S (2007). Natural regeneration of the deciduous oak species Pedunculate Oak (Quercus robur L.) and Sessile Oak (Quercrus petraea Liebl.) - a literature review with focus on wood pasture. AFSV. Waldökologie-Online, Heft 5: 79-116.

Scott D, Welch D, Thurlow M, Elston DA (2000). Regeneration of Pinus sylvestris in a natural pinewood in NE Scotland following reduction in grazing by Cervus elaphus. Forest Ecology and Management 13: 199-211. - doi: 10.1016/So3 78-1127(99)00191-7

Shaw MW (1968). Factors affecting the natural regeneration of sessile oak (Quercus petraea) in North Wales. II. Acorn losses and germination under field conditions. Journal of Ecology 56: 647-660. - doi: 10.2307/2258097

Schley L, Dufrêne M, Krier A, Frantz AC (2008). Patterns of crop damage by wild boar (Sus scrofa) in Luxembourg over a 10-year period. European Journal of Wildlife Research 54: 589599. - doi: 10.1007/s10344-008-0183-X

Schley L, Roper TJ (2003). Diet of wild boar Sus scrofa in Western Europe, with particular reference to consumption of agricultural crops. Mammal Review 33: 43-56. - doi: 10.1046/j.13652907.2003.00010.x

Spitz F, Janeau G (1995). Daily selection of habitat in wild boar (Sus scrofa). Journal of Zoology 237: 423-434. - doi: 10.1111/j.1469-7998.1995.tbo2 772.x

Tellería JL, Sáez-Royuela C (1985). Demographic evolution of the wild boar (Sus scrofa) in Spain. Mammalia 49: 195-202. - doi: 10.1515/mamm.19 85.49.2.195

Thurfjell H, Spong G, Ericsson G (2013). Effects of hunting on wild boar Sus scrofa behaviour. Wildlife Biology 19: 87-93. - doi: 10.2981/12-027

Utinek D (2004). Conversions of coppices to a coppice-with-standards in urban forests of Mo- ravský Krumlov. Journal of Forest Science 50: 38-46. [online] URL: http://www.agriculturejour nals.cz/publicFiles/55327.pdf

Van Ginkel HAL, Kuijper DPJ, Churski M, Zub K, Szafranska P, Smit C (2013). Safe for sampling not safe for seed: Quercus robur recruitment in relation to coarse woody debris in Bialowieza Primeval Forest, Poland. Forest Ecology and Management 304: 73-79. - doi: 10.1016/j.foreco. 2013.04.037

Van Wieren SF (2000). Digestibility and voluntary intake of roughages by wild boar and Meishan pigs. Animal science 71: 149-156. [online] URL: http://www.cabdirect.org/abstracts/200014149 72.html

Viewegh J, Kusbach A, Mikeska M (2003). Czech forest ecosystem classification. Journal of Forest Science 49: 74-82.

Wang W, Ma K, Lu C (1999). Removal and predation of Quercus liatungensis acorns by animals. Ecological Research 14: 225-232. - doi: 10.1046/j. 1440-1703.1999.143297.x

Wolff JO (1996). Population fluctuations of masteating rodents are correlated with production of acorns. Journal of Mammalogy 77 (3): 850856. - doi: $10.2307 / 1382690$ 